\title{
Early Cretaceous riparian vegetation in Patagonia, Argentina
}

\author{
Gerardo CLADERA ${ }^{1}$, Georgina M. Del FUEYO ${ }^{2}$, Liliana VILLAR de SEOANE $^{2}$ \& \\ Sergio ARCHANGELSKY ${ }^{2}$ \\ ${ }^{1}$ Museo Paleontológico «Egidio Feruglio», Av. Fontana 140, 9100, Trelew, Chubut, Argentina, e- \\ mail: gcladera@mef.org.ar. ${ }^{2}$ Museo Argentino de Ciencias Naturales «B. Rivadavia», Av. \\ Angel Gallardo 470, 1405, Buenos Aires, Argentina, e-mail: gdelfueyo@macn.gov.ar, \\ lilianaseo@yahoo.com.ar, sarcang@fibertel.com.ar.
}

\begin{abstract}
Early Cretaceous riparian vegetation in Patagonia, Argentina. An autochthonous plant as-semblage found at the Bajo Grande locality, Anfiteatro de Ticó Formation, Baqueró Group, Early Aptian of Santa Cruz province, Argentina, is described. Sedimentological data show an alternation of sandstone and lime-stone, with recurrent fossil levels associated to a fluvial system. The frequent flood in areas close to the levee had an influence on the vegetation growing along the banks of the channels. A plant assemblage composed of Ricciopsis grandensis nov. sp. (bryophyte), Adiantopteris tripinnata nov. sp., Schizaeaceae pinnules (ferns), and the gnetalean fructification Ephedra verticillata nov. sp. was found in this paleoenvironment. The taphonomical studies suggest that the plant assemblage was autochthonous, and it grew and was buried in an area near a levee. This result is congruent with environmental data provided by living representative of the fossil taxa analyzed.
\end{abstract}

Key words: Taphonomy, Flood plain, Bryophytes, Ferns, Ephedraceae, Baqueró Group, Early Aptian, Argentina.

The Baqueró Group (early Aptian) occurs in the Nesocratón Deseado basin in Santa Cruz province, Argentina. The deposits are continental, mostly lake and fluvial systems. Stratigraphic studies show this Group to cover volcaniclastic rocks of Jurassic age with angular unconformity. Three formations are recognized within the Baqueró Group: Anfiteatro de Ticó at the base; Bajo Tigre in the middle and Punta del Barco at the top (Cladera et al. 2002).

The Baqueró Group flora has been described since 1960, including systematic and biostratigraphy studies (Archangelsky, 1963, 1966, 1967; Menéndez, 1965, 1966; Taylor \& Archangelsky, 1985; Archangelsky \& Taylor, 1986; Archangelsky \& Del Fueyo, 1989; Del Fueyo, 1991; Villar de Seoane, 1998, 1999, 2000; among others). How-ever, the taphonomical and paleoenviromental studies of this flora are few; A. Archangelsky et al. (1995) and Cladera \& Cúneo (2002) described for the Punta del Barco Formation, a plant com-munity composed mainly of Araucariaceae, Podocarpaceae, Cycadales and Gleicheniaceae buried by airfall volcanic ash.

The purpose of this paper is to analyse the sedimentology, taphonomy and palaeoecology of a plant community composed of bryophytes, ferns and ephedracean-type fructifications found in a flood plain at a different locality. The Bajo Grande site (Figs. 1, 3A) yielded abundant fossils, including fructifications found isolated (Archangelsky
\& Villar de Seoane, 2004) or in organic connection with vegetative parts (Archangelsky, 1968).

\section{MATERIAL AND METHODS}

The specimens were collected at the Estancia Bajo Grande locality in Santa Cruz province, Argentina (Figs. 1, 3A) and referred to the Anfiteatro de Ticó Formation (Baqueró Group). Isotopic dating (Corbella, 2001), confirm that the Anfiteatro de Ticó Formation is $118.56 \pm 1.4 \mathrm{Ma}$ old (Early Aptian).

The taphonomic work was done on a $3 \mathrm{~m}^{2}$ area (Figs. 2, 3B), where the plant assemblage occurs. The fossils correspond to liverwort impressions, filicalean fronds (impressions and compressions with cuticle badly preserved), and branch com-pressions with reproductive structures of ephedracean affinity. The cuticle of the reproduc-tive structures is strongly carbonized and the treatments performed to recover the membrane showed poor results. The rock maceration gave no palynological data either. Observations were made using light (LM) and scanning electron microscopies (SEM). Classification of Tryon \& Tryon (1982) was used for ferns and Taylor \& Taylor (1993) for bryophytes and ephedracean fructifications. The specimens are stored in the Paleobotanical Collection of the Buenos Aires Natural Sciences Museum «Bernardino Riva-davia» (BA Pb, BA Pb MEB). 


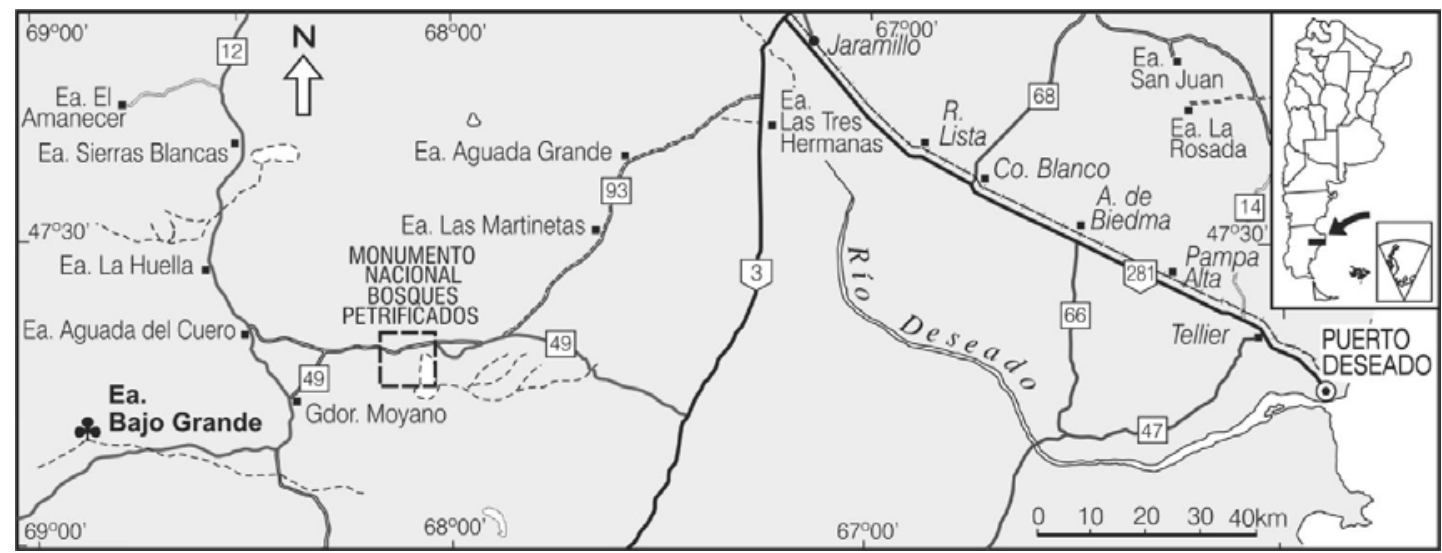

Fig. 1. Location map of the studied area.

\section{SEDIMENTOLOGICAL AND \\ TAPHONOMICAL ANALYSIS}

\section{Conglomerate and coarse sandstone chan-nel facies}

The basal surface of channel deposits is erosive and irregular, forming up to $0,30 \mathrm{~m}$ deep steeps. The channel basal fill is composed of clast-supported conglomerates with sandy matrix. The most common sedimentary structures are planar and trough-crossed bedding (Fig. $3 \mathrm{C}$ ) with me-dium scale heterogeneous sets up to $0,60 \mathrm{~m}$ (Fig, 2). Clasts attain a maximum $3 \mathrm{~cm}$ size; they are eroded from paleorelief in the underlying Chon-Aike and Bajo Grande formations (Middle Jurassic and Lower Cretaceous). The conglomerates show thickening to coarsening grain arrangements in cycles composed of associated sandstone and rarely limestone up to $1.5 \mathrm{~m}$ thick and $40 \mathrm{~m}$ wide. These channels move laterally and show a tabular geometry. The thick-medium sized sandstones with isolated clasts show trough- cross bedding structures of a maximum of $0.40 \mathrm{~m}$ divided in normal graded sets. These sandstones are usually associated with conglomerates or they form cosets up to $1.5 \mathrm{~m}$ thick. Sandstones carry wide branches and trunks 0.20 $\mathrm{m}$ in diameter. Fluvial cycles are of Gm- Gt-St type (Miall, 1985). Reactivated fluvial channels show Gm-Gt- or Gt- St cycle types, which would correspond to longitudinal bars, followed by linguoid bars showing tran-sitional contacts on sandstone. Towards the top of the sequence, coarse conglomerate facies disappear and medium sandstones with trough cross bedding dominate. The sandstone thick-ness is up to 1.5 $\mathrm{m}$ and it alternates with siltstone deposits. Paleocu rrents indicate a SE flow $\left(135^{\circ} \mathrm{N}\right)$.

\section{Floodplain fine sandstone and siltstone facies}

Floodplain deposits are up to $4 \mathrm{~m}$ thick and represented by interstratified siltstone and mudstone up to $5 \mathrm{~cm}$ thick, massive or laminated, light to dark grey in colour. These beds bear abun-dant carbonized woody fragments. Fine sand-stone beds, up to $10 \mathrm{~cm}$ thick, alternate with finer sediments of the floodplain deposits and bear well-preserved plant remains. The internal struc-ture of the sandstones is ripple crossed and lami-nated with small lenses of mudstone (Fig. 3D). The alternation of sandstone and mudstone beds occurs five times in the floodplain sequence. Paleosols including $1 \mathrm{~cm}$ long by $3 \mathrm{~mm}$ diameter roots are also commonly found in this alternated sequence. The contact surface between the sand-stone beds and finer sediments is both sharp and undulating.

\section{Interpretation}

The conglomerate facies (Gm-Gt) was deposited under low energy conditions (Reineck \& Singh, 1980). The St facies can be interpreted as a channel fill (Reineck \& Singh, 1980), or else as migration of transversal bars with linguoid crests (Allen 1983; Miall, 1983, 1996). At times this facies tends to fill the deepest part of the channel forming conglomerate-sandstone bars. In some cases, the erosive surfaces are interpreted as a fluctuation in the flow stages. Thus, the channel fill is made of conglomerate- sandstone (Gm-Gt-St), while abandoned facies are represented by siltstone as cycles of Gm-Gt-St-Fm type. Fine-grained cycles are of St-Fm-FI-Fr type, and characterize flood plain deposits laterally associated with channels. This plain was formed by an almost continuous sedimentation of fine sediments by overbank flooding and crevasse 


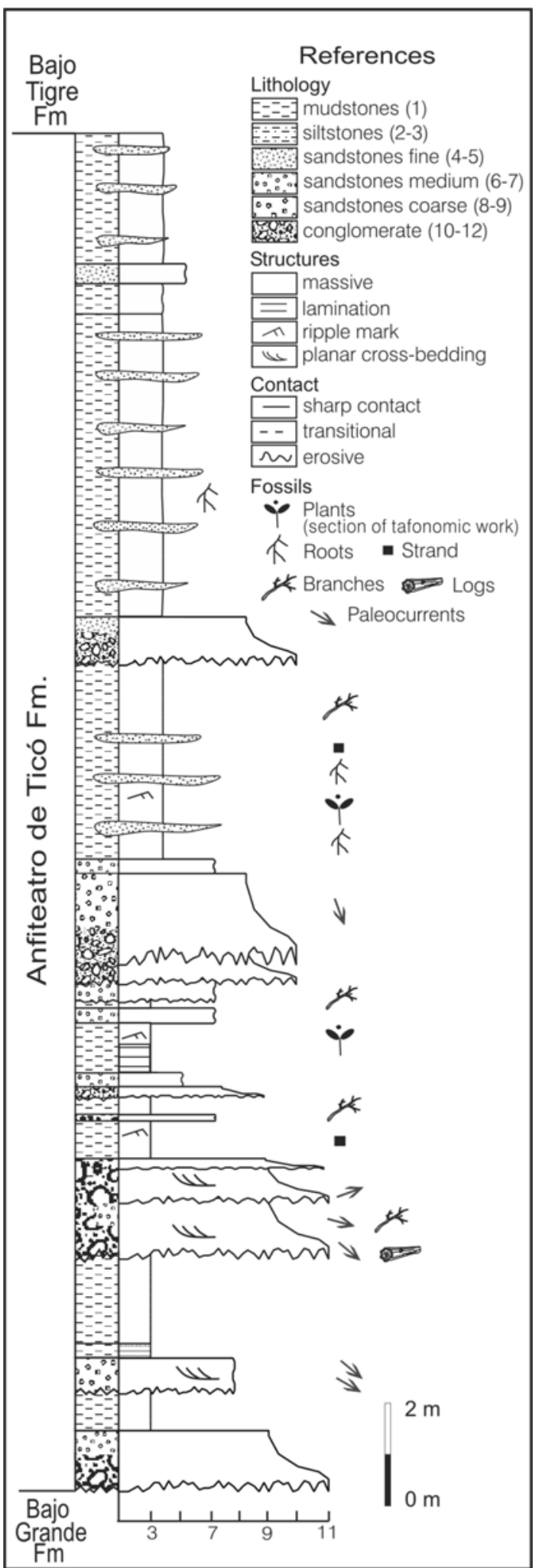

Fig. 2. Stratigraphic section showing location of the fossiliferous beds. splay represented by sandstone beds. Paleosols indicate interruptions in sedimentation. This facies association may have been part of a levee, as indicated by a high sandstone/ siltstone ratio due to a constant river rising. Based on the characteristics of the associated facies, a low energy of a moderate sinuosity river is suggested.

Plint (1983) has described similar facies for the Middle Eocene of the Hampshire basin in England, while Cladera et al. (2002) indicate similar fluvial styles in other areas of the Deseado Nesocraton.

\section{Taphonomy}

Our observations are based on the $3 \mathrm{~m}^{2}$ where the plant remains were found. A detailed exami-nation of the surrounding sediments of the fossiliferous area was conducted (both laterally and vertically) but no plant remains were found.

The following taxa were found (percent values show proportion of specimens of each taxon): Adiantopteris (49,2\%); gnetalean fertile fragments (46,5\%); a Schizaeaceae frond (1,54\%) and Ricciopsis sp. (3,07\%).

The fern Adiantopteris includes tripinnate fronds without any preferable orientation and crossing the bedding plane (both the sandstones and laminated siltstone), and its pinnule toothed margins and apex are well preserved.

The fragmentary impressions of the ephedracean fertile plant are composed of third order and lower branches with a maximum size of $10 \mathrm{~cm}$ long and $0.2 \mathrm{~cm}$ wide. Like Adiantopteris remains, these fragments are found with no preferred orientation and cross several bedding planes. The margins of the delicate terminal fructifications are perfectly preserved, indica-ting the absence of water transport. Although these ephedracean fructifications show no evi-dence of aquatic transport, they are not attached to the vegetative parts.

\section{SYSTEMATICS}

Division HEPATOPHYTA Smith 1972

Order MARCHANTIALES Smith 1972

Family RICCIACEAE Smith 1972

Genus Ricciopsis Lundblad 1954

Type species. Ricciopsis florinii Lundblad 1954

\section{Ricciopsis grandensis nov. sp.} (Fig. 4 A)

Holotype. BA Pb 13504.

Other studied material. BA Pb 13505. 

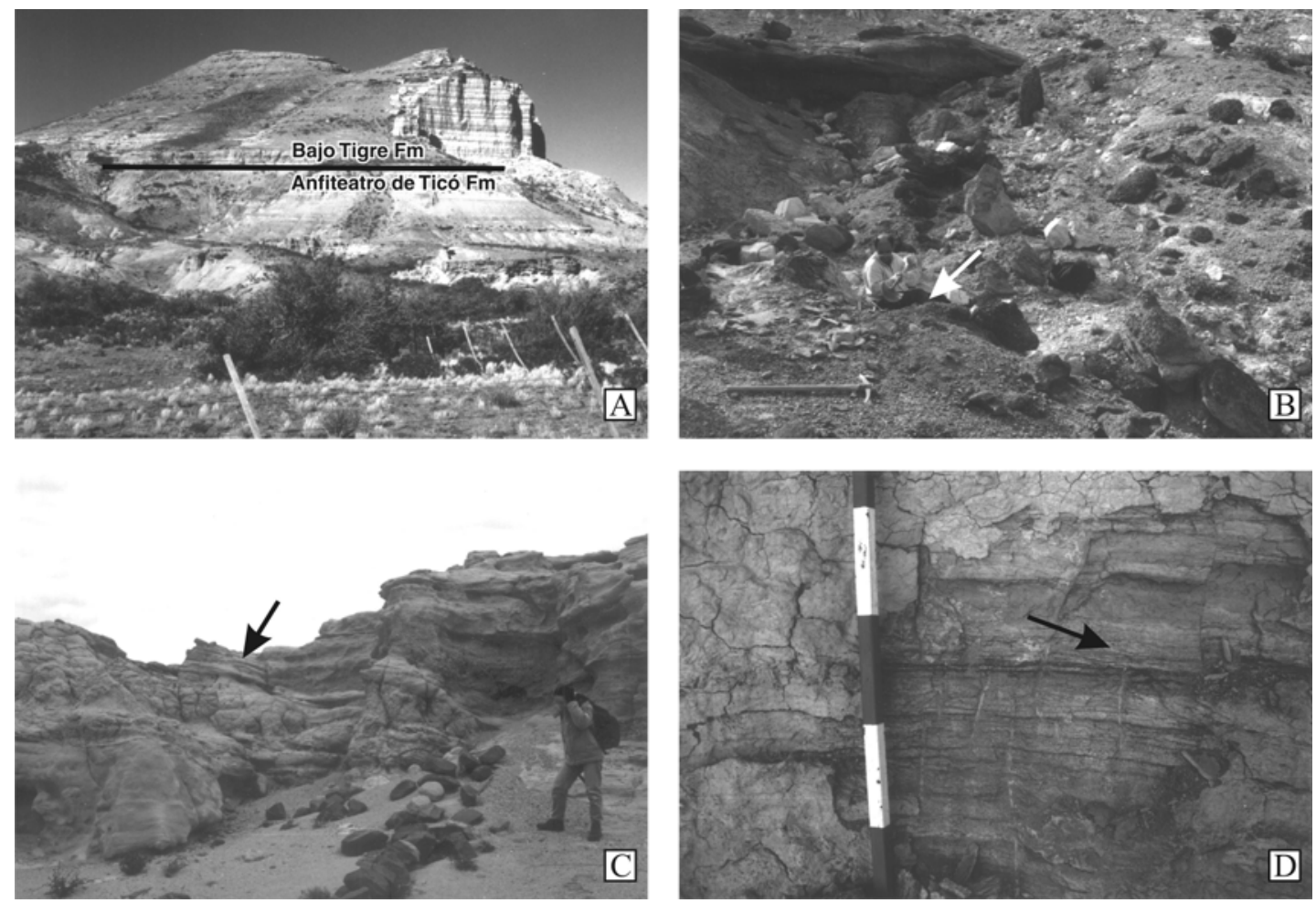

Fig. 3. A-D. Bajo Grande Locality. A. Bajo Grande Locality general view. The line separates beds of the Anfiteatro de Ticó Formation (below) and Bajo Tigre Formation (above). B. Fossiliferous level (white arrow). C. View of a fluvial channel. Arrow shows the through-cross bedding structures. D. Detail of the floodplain where the alter-nation of sandstone and mudstone beds can be observed. Arrow indicates the ripple crossed.

Locality. Estancia Bajo Grande, Santa Cruz Province, Argentina.

Stratigraphic horizon. Baqueró Group, Anfiteatro de Ticó Formation, Early Cretaceous (Aptian).

Etymology. The specific name refers to the fossiliferous locality where the specimens have been recovered.

Diagnosis. Plant thalloid. Thalli in groups, forming rosettes up to $1.5 \mathrm{~cm}$ in diameter. Thallus branched dichotomously up to three times. Branches ranging from $0.10-0.20 \mathrm{~cm}$ wide and $0.20-0.50 \mathrm{~cm}$ long. Entire margins, rounded apex and strongly marked midrib.

Description. The specimens are represented by impressions belonging to fragments of a ro-setteshaped thallus up to $1.5 \mathrm{~cm}$ in diameter. The thallus has several dichotomous branches which are divided up to three times. It seems that the complete rosette may have had six main branches from the centre. Each branch is linear to wedge-shaped with a strongly marked midrib on the dorsal side, showing entire margins that end in a rounded apex. The first order branch is $0.15-$ $0.20 \mathrm{~cm}$ wide and $0.50 \mathrm{~cm}$ long while the second order branch is $0.10-0.20 \mathrm{~cm}$ wide and $0.20 \mathrm{~cm}$ long and the last order branch is $0.07 \mathrm{~cm}$ wide and $0.20-0.40 \mathrm{~cm}$ long. Due to preservation no rhizoids were observed.

Remarks. The oldest bryophyte megafossil remains in Argentina occur in the Upper Carboniferous of San Juan province, where Muscites amplexifolius was described by Ottone \& Archangelsky (2001). For the Mesozoic, only one bryophyte was described by Halle in 1913. He studied small fragments of Marchantites sp. from mid-Cretaceous sediments of the Lago San Martín (Santa Cruz province). Later Lundblad (1955) assigned these specimens to $M$. hallei.

Ricciopsis grandensis represents the first record of Ricciaceae in Argentina. The compari-son with other described species from Sweden and Iran (Oostendorp, 1987), shows the follow-ing differences. R. florinii Lundblad (1954) from the Early Jurassic of Skromberga, Scania prov-ince (Sweden), differs by having a larger and crowded rosette-thalli of $2.5 \mathrm{~cm}$ in diameter. From 
the same locality, Lundblad (op. cit.) also recorded $R$. scanica which is smaller $(1 \mathrm{~cm}$ in diameter) and has four main branches. $R$. iranica Fakhr (1975) from Zhurab locality (Late TriassicEarly Jurassic of Iran), has small star-like thalli (1 $\mathrm{cm}$ in diameter) and narrower branches (up to 0.1 $\mathrm{cm})$.

The presence of liverworts in the Baqueró Group is also confirmed through the palynological analyses made by Archangelsky \& Villar de Seoane (1996), who studied several spore species of bryophyte, among which two have suggested

Riccia affinities (Naiaditaspora gemmata

Archangelsky \& Villar de Seoane and Coptospora foveolata Archangelsky \& Villar de Seoane).

Occurrence. Living hepatics occur in polar, temperate and mainly in tropical areas, where they are found related with shady and moist terrestrial habitats (Smith, 1972). Riccia can be terrestrial or aquatic, living on the shore of rivers and brooks. However, certain species are truly aquatics and grow floating on the water surface (Watson, 1971). According to this, the thalli morphology varies from a rosette type to a filiform type, respectively.

\section{Division PTERIDOPHYTA Tryon \& Tryon 1982}

Class FILICOPSIDA Tryon \& Tryon 1982

Order POLYPODIALES Tryon \& Tryon 1982

Family PTERIDACEAE Tryon \& Tryon 1982

Genus Adiantopteris Vassilevskaja 1963 (in

Tajtadzhan, Vajrameiev \& Radchenko 1963)

Type species. Adiantopteris sewardii (Yabe, 1905) Vassilevskaja 1963 (in Tajtadzhan, Vajrameiev \& Radchenko 1963)

\section{Adiantopteris tripinnata nov. sp.} (Figs. 4 B, C)

Holotype. BA Pb $13514 \mathrm{a}, \mathrm{b}$.

Paratypes. BA Pb 13509 a, b.

Other studied material. BA $\mathrm{Pb} 13504, \mathrm{BA} \mathrm{Pb}$ 13505, BA Pb 13508, BA Pb 13510, BA Pb 13511, BA Pb 13512, BA Pb 13513, BA Pb 13516, BA Pb 13517 a, b, c, BA Pb 13519, BA Pb MEB 186.

Locality. Estancia Bajo Grande, Santa Cruz Province, Argentina.

Stratigraphic horizon. Baqueró Group, Anfiteatro de Ticó Formation, Early Cretaceous (Aptian).

Etymology. The specific name refers to the ramification order of the leaf fragments.

Diagnosis. Leaves imparipinnate, bipinnate and tripinnate. Rachises strong and slender. Pin- nae triangular in shape. Pinnules simple, subopposite, small and sessile or sub- petiolate; flabelliform, up to $10 \mathrm{~mm}$ long and $2 \mathrm{~mm}$ wide. Laminae divided in two to four cuneiform segments with straight margins and dentate apex. Teeth concentration 1 to 2 per millimeter. Only one principal vein radiates and divides dichotomously several times innerving each tooth.

Description. The fronds are represented by impressions approximately $6.2 \mathrm{~cm}$ long and 2.3 $\mathrm{cm}$ wide (Fig. $4 \mathrm{~B}$ ). The leaves are imparipinnate and bipinnate, but in the specimen BA Pb 13514 $a, b$, the frond disposition suggests a tripinnate organization (Fig. 4 B). They have strong and slender rachises $4.7 \mathrm{~cm}$ long and $0.1 \mathrm{~cm}$ wide. The pinnae are up to $2.5 \mathrm{~cm}$ long and $1.5 \mathrm{~cm}$ wide and have a triangular shape; the pinnules are simple, the basal one being petiolate and the most apical completely sessile (Fig. $4 \mathrm{C}$ ). The laminae are divided into two to four segments 5 $\mathrm{mm}$ deep and $2 \mathrm{~mm}$ wide. The segments are cuneiform, united by only one decurrent base with an inser-tion angle of approximately $45^{\circ}$. In some speci-mens, the segments may overlap. They have a dentate apex and straight margin, one is parallel while the other is perpendicular to the rachis. The teeth are separated from each other by a deep U-shape or V-shape valley, ending in an acute apex (Fig. $4 \mathrm{C}$ ). The principal vein radiates from the base and divides dichotomously several times, tri to pentafurcate. The concentration is about 3 veins per millimeter. Each vein ends in a corres-ponding distal tooth.

Remarks. Adiantopteris was created by Vassilevskaja (in: Tajtadzhan et al., 1963, pp. 586) for Mesozoic-Neogene sterile fronds similar to the living Adiantum. Most Adiantopteris species were recorded from Jurassic to Miocene beds of Laurasia (Tajtadzhan et al., op.cit.), A. tripinnata being the first recorded Cretaceous find of Patagonia. The pinnules of Adiantopteris sewardii described by Yabe (1905) from the Up-per Jurassic-Lower Cretaceous of Korea are larger (15 mm long) and have fewer segments.

Adiantopteris prigorovskii Vachrameev 1952 from the Albian of Kazakhstan has smaller pinnules ( 7 $\mathrm{mm}$ long), the lamina is entire and more expanded in outline. In Patagonia, Berry (1928) illustrated Adiantum patagonicum from the Tertiary of Santa Cruz Province. It has iso-lated and larger $(3 \mathrm{~cm})$ stipitate pinnules, and is divided into two terminal and two lateral more or less bisected lobes.

Palynological records from the Anfiteatro de Ticó Formation show the presence of adiantacean spores as Leiotriletes regularis (Pflug) Krutzsch (Archangelsky \& Villar de Seoane, 1994). 
Occurrence. Adiantum contains about 150 species, widely distributed in pantropical regions. It also extends south to southern South America to Alaska, New Zealand and northeastern Asia, except in areas with extremely cold or dry climates (Tryon \& Tryon, 1982).

\section{Family SCHIZAEACEAE Tryon \& Tryon 1982}

\section{Genus Incertae Sedis}

(Fig. 4 D)

Studied material. BA Pb $13514 \mathrm{a}$ and b.

Locality. Estancia Bajo Grande, Santa Cruz Province, Argentina.

Stratigraphic horizon. Baqueró Group, Anfiteatro de Ticó Formation, Early Cretaceous (Aptian).

Description. The material consists of a leaf impression $3 \mathrm{~cm}$ long and $1.5 \mathrm{~cm}$ wide. The leaf is imparipinnate and has a triangular shape. The rachis is $1 \mathrm{~mm}$ wide, slender and straight. The pinnae decrease in size toward the apex, from $9 \mathrm{~mm}$ long (the basal) to $2 \mathrm{~mm}$ long (the apical) and 3 to 1 $\mathrm{mm}$ wide respectively. They are falcate with rounded apex, lobulate margins and asym-metrical base with the anadromic side wider than the catadromic side, that is almost parallel to the rachis. The lobes in the basal pinnae are deeply divided, originating up to four incipient impa-ripinnate and opposite pinnules. The pinnae have a middle vein and bifurcated secondary veins.

Remarks. This leaf impression is included in the Schizaeaceae because its morphology is very similar to the living Anemia, especially $A$. glareosa Gardn. that lives in the South Ameri-can tropics (Tryon \& Tryon, 1982, p. 64, fig. 6.12). Among the sterile Anemia-type fossils, two genera are known that differ from the specimen here described: Aneimidium Schimper, 1869 from the Lower Cretaceous of Germany, that has flabelliform pinnules, and Aneimites (Dawson) Ettingshausen, 1865 from the Carboniferous of Germany, with seven to three lobed pinnules.

Occurrence. Anemia is found in open habitats and well- drained sites of the American tropics, growing on ravine banks, stream borders, shrubby hillsides, small cliffs and sometimes it grows in savannahs, open forests or rain forests (Tryon \& Tryon, 1982).

\section{Division GNETOPHYTA Gifford \& Foster 1989}

Order GNETALES Gifford \& Foster 1989

Family EPHEDRACEAE Gifford \& Foster 1989
Genus Ephedra Linné 1753

Type species. Ephedra distachya Linné 1753

\section{Ephedra verticillata nov. sp.}

(Figs. $4 \mathrm{E}-\mathrm{I}$ )

Holotype. BA Pb 13521 a and b

Paratype. BA Pb 13524

Other specimens studied. BA Pb13506, $13507,13515,13519,13520,13522,13523$, 13525 a, b, 13526, 13527, 13528; BA Pb MEB 187, 188 and 189.

Locality. Estancia Bajo Grande, Santa Cruz Province, Argentina.

Stratigraphic horizon. Baqueró Group, Anfiteatro de Ticó Formation, Early Cretaceous (Aptian).

Etymology. The specific epithet refers to the whorl arrangement of branches.

Diagnosis. Stems with verticillate branches and seed-bearing structures. Third order branches in whorls of three to six per node. Stems and branches with ridges, up to $0.2 \mathrm{~cm}$ wide and $2.2 \mathrm{~cm}$ long. Seed-bearing structures single or in clusters of three to five, sessile, rounded to oval in outline and up to $0.15 \mathrm{~cm}$ wide and $0.20 \mathrm{~cm}$ long. Each structure with two oval-acuminate seeds $0.8 \mathrm{~mm}$ wide and $1.8 \mathrm{~mm}$ long.

Description. The specimens are compressions of fertile fragments represented by straight and strong stems with verticillate branches ending in seedbearing structures (Fig. $4 \mathrm{E}$ ). Most of the material shows up to third order branches occur-ring in whorls of three to six per node (Fig. 4 F). The stems and branches have longitudinal ridges and no scales or leaves are observed. The stems are 0.07-0.2 cm wide and 1.0-2.2 cm long (incom-plete). The first order branches are $0.2 \mathrm{~cm}$ wide and vary from 0.5 $3.9 \mathrm{~cm}$ in length; the second order branches are 0.1$0.2 \mathrm{~cm}$ wide and $1.2-2.5 \mathrm{~cm}$ long; finally, the paratype is $0.05-0.15 \mathrm{~cm}$ wide and $0.4-1.2 \mathrm{~cm}$ long. At the end of these branches seed- bearing structures are born, which can be single or in clusters of three to five units (Figs. $4 \mathrm{G}, \mathrm{I}$ ). These fertile organs are sessile and rounded to oval in outline and up to $0.15 \mathrm{~cm}$ wide and $0.20 \mathrm{~cm}$ long. Each structure bears two oval-acu-minate seeds 0.8 $\mathrm{mm}$ wide and $1.8 \mathrm{~mm}$ long, which have a striate surface (Fig. $4 \mathrm{H}$ ). In some specimens, the seeds are subtended by a pair of bracts up to $2 \mathrm{~mm}$ long.

Remarks. Mesozoic gnetalean mega-fossil remains occur in few regions. Ephedra archaeorhytidosperma described by Yang et al. (2005) from the Barremian Yixian Formation, China, is the 

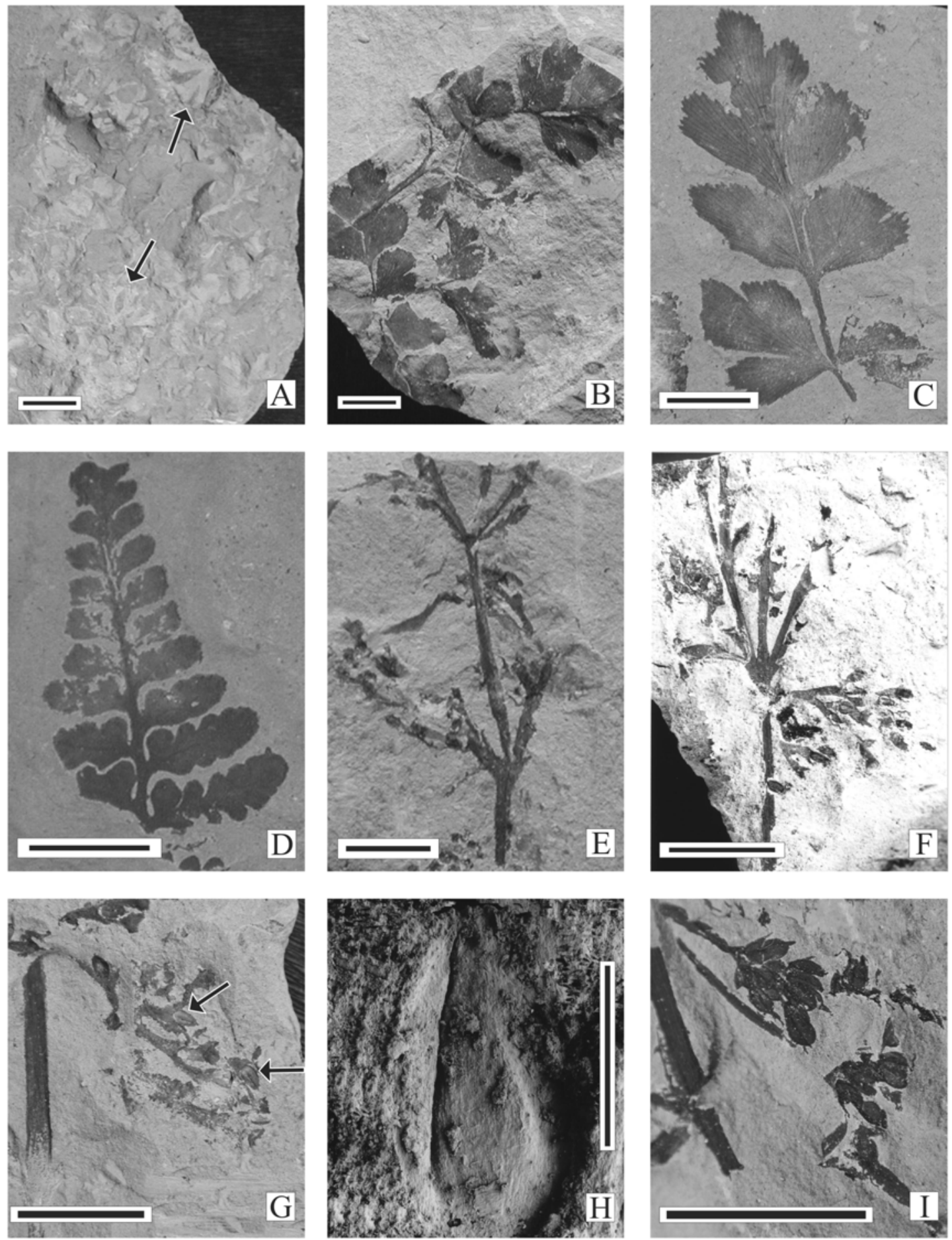

Fig. 4. A- I, Plant assemblage. A. Ricciopsis grandensis nov. sp., general aspect of the rosette-shaped thalli (arrows), holotype: BA Pb 13504. B-C. Adiantopteris tripinnata nov. sp., B. General view of a frond fragment, holotype: BA Pb 13514 a. C. Detail of a pinna, paratype: BA Pb 13509 b. D. Schizaeaceae, fragment of a pinna, BA Pb 13509 b. E-I. Ephedra verticillata nov. gen. et sp. E, F. General aspect of the verticillate branches and seedbearing structures, holotype: BA Pb 13521 a, BA Pb 13523. G, last order branch with single fertile organs (arrows). H. Detail of a fertile organ. G, H. paratype: BA Pb 13524. I. Clusters of fertile organs, BA Pb 13506. 
most similar species to E. verticillata. The Chinese specimens differ in having isolated leaves near the nodes and larger seeds (1.5 $-4 \mathrm{~mm}$ long and 1- $1.6 \mathrm{~mm}$ broad) with cuticle preserved. Among other described taxa, the differences with Ephedra verticillata are notably marked: Dinophyton spinosum Ash (1970) from the Upper Triassic of Arizona has shoots with needle-like leaves (less than $2 \mathrm{~mm}$ ) with uniovulate lobed cupules $2.6 \mathrm{~mm}$ long and $1 \mathrm{~mm}$ wide (Krassilov \& Ash, 1988). Four different seed- bearing organs from the Middle Jurassic of East Siberia (Krassilov \& Bugdaeva, 1988) were characterized by having one ovule ranging from 5- $20 \mathrm{~mm}$ long and subtended by axillary bracts. Drewria potomacensis from the Early Cretaceous of the Potomac Group of Virginia shows stems with sim-ple and oblong leaves and terminal or axillary reproductive structures containing flattened seeds surrounded by one pair of elliptical ovate bracts (Crane \& Upchurch, 1987). A Gnetophyte assemblage from the Early Cretaceous of Transbaikalia presents four new genera of seed-bearing reproductive organs with different morphology that vary from cupules with one-four ovules each to flower-like structures (Krassilov \& Bugdaeva, 2000). More recently, coalified seeds closely related with the living Ephedra from the Early Cretaceous of Portugal, were described as small seeds between 850 and $1200 \mu \mathrm{m}$ long with a rounded base and pointed micropyle (Rydin et al., 2004).

Palynological data from the Baqueró Group also confirm the presence of the family Ephedraceae through Ephedripites (Equisetosporites) spp. (Archangelsky \& Villar de Seoane, pers. com.).

Occurrence. The Ephedraceae live in temperate and tropical regions of Asia, southern Europe and northern Africa. In America, it grows in subtropical regions, in deserts and meadows of the warmer zones (Krüssmann, 1985).

\section{CONCLUSIONS}

The Anfiteatro de Ticó Formation was deposited under fluvial and lacustrine conditions. The sequences of the facies with thickening to coarse grain arrangements and the geometry of tabular bodies, together with lateral displacements, suggest that the fluvial system was meandriform.

The fine deposits are associated with accretion deposits due to main flow floods in the plain or as abandoned channel fills. This type of flu-vial system is very common in all the areas where the Anfiteatro de Ticó Formation is found (Cla-dera et al., 2002).
The sandstone and limestone alternation together with the recurrent fossil levels formed by successive flooding of the levee. This was associated with vegetation growing along the banks of the channel, mainly composed of

Adiantopteris tripinnata and Ephedra ver-ticillata, a type of plants that is found only near a levee.

The repetition of this taphocenoces, associated with the levee facies, show a clear cycling scheme of a recurrent vegetation, related to the same sedimentary facies.

The combination of data show that Adiantopteris tripinnata and Ephedra verticillata were autochthonous, growing and being buried in the area near the levee.

This kind of taphofacies was not found in other sites where the Anfiteatro de Ticó Formation crops out. This unit contains numerous fossiliferous levels that mostly show evidence of transport.

Perhaps, this peculiar topographic setting is responsible of the unique plant assemblage that includes taxa that were not mentioned before, among a large list that includes more than 100 species. In fact the genera Ephedra, Ricciopsis and Adiantopteris are new records for the Anfiteatro de Ticó Formation.

The same section yields abundant fossils in facies in which some transport of plant debris was evident. These allochthonous fossils are very well preserved, however. Fine grained sediments have yielded many fragments of plants, some with their fructifications still attached (Apterocladus Archangelsky, 1966; Androstrobus Archangelsky \& Villar de Seoane, 2004).

The present finding underscores the need for further taphonomic research of this for-mation and demonstrates that in spite of the large number of taxa that have been described, there is more room for new findings that will improve our knowledge of the Ticó palaeoco-munities.

\section{ACKNOWLEDGMENTS}

This work was partially funded by grants BID 1201 PICT 99/6044 «Cretácico inferior de la Patagonia Austral. Fitoestratigrafía de áreas seleccionadas» and PIP CONICET 5093 «Estudios Paleobotánicos y Palinológicos en el Cretácico Inferior de la Cuenca Austral, Santa Cruz». The authors are grateful to Drs. Gregory Retallack and Rafael Herbst for useful comments which have improved the manuscript, also to Amalia González for draughting figures 1 and 2. 


\section{BIBLIOGRAPHY}

Allen, J. R. L. 1983. Studies in fluviatile sedimenta-tion: bars, bar complexes and sandstone sheets (low sinuosity braided streams) in the Browstones ( $L$. Devonian), Welsh Borders. Sedimentology Geol. 33: 237 - 293.

Archangelsky, A., R. Andreis, S. Archangelsky \& A. Artabe. 1995. Cuticular characters adapted to volcanic stress in a new cretaceous cycad leaf from Patagonia, Argentina. Considerations on the stratigraphy and depositional history of the Baqueró Formation. Rev. Palaeobot. Palyn. 89:213-233.

Archangelsky, S. 1963. A new Mesozoic flora from Ticó, Santa Cruz Province, Argentina. Bull. Brit. Mus. (Nat. Hist.), Geol. 8:45-92.

1966. New Gymnosperms from the Ticó Flora, Santa Cruz province, Argentina. Bull. Brit. Mus. (Nat. Hist.), Geol. 13: 259- 295.

- 1967. Estudio de la Formación Baqueró, Cretácico Inferior de Santa Cruz, Argentina. Revista del Museo de La Plata (Nueva Serie) Paleontología, 5: 63-171.

- 1968. On the genus Tomaxellia (Coniferae) from the Lower Cretaceous of Patagonia (Argentina) and its male and female cones. Bot. J. Linn. Soc. 61:153-165.

Archangelsky, S. \& G. M. Del Fueyo. 1989. Squamastrobus gen. nov., a fertile podocarp from the Early Cretaceous of Patagonia, Argentina. Rev. Palaeobot. Palynol. 59: 109-126.

Archangelsky, S. \& T. N. Taylor. 1986. Ultrastructura studies of fossil plant cuticles. II. Tarphyderma gen. n., a cretaceous conifer from Argentina. Amer. J. Bot. 73: 1577-1587.

Archangelsky, S. \& L. Villar de Seoane. 1994. Estudios palinológicos de la Formación Baqueró (Cretácico), provincia de Santa Cruz, Argentina. VI. Ameghiniana 31: 41-53.

- 1996. Estudios palinológicos de la Formación Baqueró (Cretácico), provincia de Santa Cruz, Argentina. VII. Ameghiniana 33: 307-315.

- 2004. Cycadean diversity in the Cretaceous of Patagonia, Argentina. Three new Androstrobus species from the Baqueró Group. Rev. Palaeobot. Palynol. 131: 1-28.

Ash, S. R. 1970. Dinophyton, a problematical new plant genus from the Upper Triassic of south-western United States. Palaeontology 13: 646-663.

Berry, E.W. 1928. Tertiary fossil plants from the Argentine Republic. Proc.U.S. Nat. Mus. 73: 1-27.

Cladera G. \& R. Cúneo. 2002. Fossil plants buried by volcanic ash in the Lower Cretaceous of Patagonia. In: De Renzi, M., Pardo Alonso, M. V., Belinchon, M., Peñalver, E., Montoya, P. and Marquez-Aliaga, A. (eds.), Current Topics on Taphonomy and Fossilization. Valencia, pp.399- 403

Cladera, G., R. Andreis, S. Archangelsky \& R. Cúneo. 2002. Estratigrafía del Grupo Baqueró, Patagonia (provincia de Santa Cruz, Argentina). Ameghiniana, 39:3-20.

Corbella, H. 2001. Tuffs of the Baqueró Group and the Mid-Cretaceous frame Extra andean Patagonia,
Argentina. $11^{\circ}$ Congreso Latinoamericano de Geología y 3 Congreso Uruguayo de Geología. Paper 190 7, 6pp (CD).

Crane, P. R \& G. R. Upchurch.1987. Drewria potomacensis gen et sp. nov., an Early Cretaceous mem-ber of Gnetales from the Potomac Group of Virginia. Am. J. Bot. 74: 1722-1736.

Del Fueyo, G. 1991. Una nueva Araucariaceae cretácica de Patagonia, Argentina. Ameghiniana 28: 149-161.

Ettingshausen, C. 1865. Die Farnkräuter der Jetztwelt Carl Gerold's Son, Vienna, pp 298.

Fakhr, M. M. S. 1975. Contribution a l'étude de la flore rhéto-liasique de la formation de Shemshak de l'Elbourz (Iran). Publication du Laboratoire de Paléobotanique de l'Université Paris. VI, 2 CNRS-A. O.10517.

Halle, T. G. 1913. Some mesozoic plant-bearing deposits in Patagonia and Tierra del Fuego and their floras. K. svenska Vetensk Akad. Handl. 51: 1-58.

Krassilov, V. A. \& S. R. Ash. 1988. On DinophytonProtognetalean Mesozoic plant. Palaeontographica B 208: 33-38.

Krassilov, V. A. \& E. V. Bugdaeva. 1988. Gnetalean plants from the Jurassic of Ust- Balej, East Siberia. Rev. Palaeobot. Palynol. 53: 359-374.

2000. Gnetophyte assemblage from the Early Cretacous of Transbaikalia. Palaeontographica B 253: 139-151.

Krüssmann, G. 1985. Manual of cultivated conifers. Timber Press. Portland- Oregon. pp. 361.

Linné, C. 1753. Species Plantarum, pp. 1040. Lundblad,

B. 1954. Contributions to the geological history of the Hepaticae. Fossil Marchantiales from the Rhaetic-Liassic coalmines of Skromberga (Prov. of Scania), Sweden. Svensk Botanisk Tidskrift 48: 383-417.

1955. Contributions to the geological history of the Hepaticae. II. On a fossil member of the Marchantiineae from the Mesozoic plant- bearing depos-its near Lago San Martin, Patagonia (Lower Creta-ceous). Botaniska Notiser 108: 22-39.

Menéndez, C. A. 1965. Sueria rectinervis nov, gen et sp. de la flora fósil de Ticó, Provincia de Santa Cruz. Ameghinina 4: 3-11.

1966. Fossil Bennettitales from the Tico Flora, Santa Cruz province, Argentina. Bull. Brit. Mus. (Nat. Hist.) Geol. 12:1-42.

Miall, A. D. 1983. Basin analysis of fluvial sediments. In: Collinson JD, Lewin JL (eds) Modern and an-cient fluvial systems. Spec. Publs. Int. Sediment. 6: 279286

- 1985. Architectural element analysis: a new method of facies analysis applied to fluvial deposits. Earth Sci. Rev. 22: 261-308.

- 1996. The geology of fluvial deposits. SpringerVerlag Berlin-Heidelberg, pp. 582.

Oostendorp, C. 1987. The Bryophytes of the Palaeozoic and the Mesozoic. Bryophytorum Bibliotheca, 34. J. Cramer (ed.). Berlin, pp. 112.

Ottone, E. G. \& S. Archangelsky. 2001. A new bryophyte from the Upper Carboniferous of Argentina. Ameghiniana 38: 219-223.

Plint, A. G. 1983. Facies, environments and sedimentary cycles in the Middle Eocene Bracklesham For- 
mation of the Hampshire Basin: Evidence for glo-bal sea-level changes? Sedimentology 30: 625-653.

Reineck, H. E. \& I. B. Singh. 1980. Depositional sedimentary environments, with reference to terrigenous clastics. 2d, Springer - Verlag, New York, pp. 549.

Rydin, C., K. R. Pedersen \& E. M. Friis. 2004. Early Cretaceous evidence for an ancient origin of Ephedra. $7^{\circ}$ International Organization of Paleobotany Conference. Abstracts, Bariloche, Argentina, pp. 98.

Schimper, W. P. 1869-74. Traité de paléontologie végétale ou la flore du monde primitif, J.B. Bailliere et fils, Paris, 1: 1-740.

Smith, G. 1972. Crytogamic Botany. Bryophytes and Pteridophytes. Volume II. TMH Edition, New Delhi, pp. 399.

Tajtadzhan, A. L., V. A. Vajrameiev \& G. P. Radchenko. 1963. Algae, Musci, Psilophytes, Lycopodiales, Sphenophytes and Ferns. In: I.A. Orlov (ed.) Principles of Palaeobotany., 4. Ac. Cs. URSS. pp. 698. (In russian).

Taylor, T. N. \& S. Archangelsky. 1985. The cretaceous pteridosperms Ruflorinia and Ktalenia and implications on cupule and carpel evolution. Amer .J. Bot. 72:1842-1853.

Taylor, T. N. \& E. L.Taylor. 1993. The Biology and Evo- lution of Fossil Plants. Prentice Hall, New Jersey, pp. 982.

Tryon, R. M. \& A. F. Tryon. 1982. Ferns and Allied Plants. With Special Reference to Tropical America. Springer-Verlag, New York, pp. 857.

Vachrameev, V. 1952. Stratigraphy and fossil flora of the Western Kaszastan cretaceous beds. In: Regional Stratigraphy of URSS, 1, pp. 258 (in russian).

Villar de Seoane, L. 1998. Comparative study of extant and fossil conifer leaves from the Baqueró Formation (Lower Cretaceous), Santa Cruz Province, Argentina. Rev. Palaeobot. and Palynol. 99: 247-263.

- 1999. Otozamites ornatus sp. nov., a new bennettitalean leaf species from Patagonia, Argentina. Cret. Res. 20: 499-506.

- 2000. Ruflorinia papillosa sp. nov. from the Lower Cretaceous of Patagonia, Argentina. Palaeontographica B, 255: 79-85.

Watson, E. U. 1971. The structure and life of Bryophytes. Hutchinson, London, pp. 211.

Yabe, H. 1905. Mesozoic plants from Korea. Journ. Coll. Sci. Univ. Tokyo, 20: 13-28.

Yang, Y., B. Geng, D. L. Dilcher, Z. Chen \& T.A. Lott. 2005. Morphology and affinities of an Early Cretaceous Ephedra (Ephedraceae) from China. Am. J. Bot. 92: 231-241. 